\title{
Extended distal pancreatectomy with thoracic wall resection after neoadjuvant FOLFIRINOX: Is there a limit of resection for pancreatic cancer after downstaging?
}

\author{
Tommaso Giuliani ${ }^{1}$, Maria López Rubio², Eva Montalvá Oron², Javier Maupoey Ibañez ${ }^{2}$, \\ Andrea Boscá Robledo ${ }^{2}$, Cecilia López Valdivia ${ }^{3}$, Judith Pérez Rojas ${ }^{3}$, and Rafael Lopez Andujar ${ }^{2}$ \\ ${ }^{1}$ Department of General and Pancreatic Surgery, University of Verona, The Pancreas Institute, Verona Hospital Trust, \\ Verona, Italy, Departments of ${ }^{2}$ HPB Surgery and Transplants, and ${ }^{3}$ Pathology, Hospital Universitario La Fe, Valencia, Spain
}

\begin{abstract}
Indications and outcomes of extended pancreatectomies have been recently appraised by the International Study Group for Pancreatic Surgery. However, no definitive conclusions have been drawn, particularly in the setting of neoadjuvant treatments. We present here a case of 53-year-old man diagnosed with a bulky adenocarcinoma of the tail of the pancreas and infiltrating the adjacent organs and the thoracic wall. The patient was sent to neoadjuvant chemotherapy and he underwent 12 cycles of FOLFIRINOX. Since a significant radiological response was observed after chemotherapy, the patient was scheduled for extended distal pancreatectomy with en bloc resection of the thoracic wall, in order to achieve a radical resection. The surgery is herein described with all technical details. The patient was discharged after an uneventful early post-operative course and subsequently readmitted for a late grade B post-operative pancreatic fistula, which was ultimately treated successfully. Pathology showed complete response. When performed in centers with ample experience in pancreatic surgery, extended pancreatic resections represent a viable curative option with acceptable surgical outcomes. In this setting, challenging tailored resections should be considered to achieve negative margins, particularly following maximized effective downstaging strategies. (Ann Hepatobiliary Pancreat Surg 2020;24:90-96)
\end{abstract}

Key Words: Pancreatic surgery; FOLFIRINOX; Extended pancreatectomy; Multivisceral resection

\section{INTRODUCTION}

Microscopic radical resection (R0) is a key predictor of long-term outcome in patients with non-metastatic pancreatic cancer. ${ }^{1,2}$ Borderline resectable and locally advanced tumors can involve adjacent organs or vascular structures. Thus, they potentially require extended pancreatectomy to achieve a curative radical resection. ${ }^{3-6}$ Over the past decades, heterogeneous definitions of extended pancreatectomy and the indiscriminate use of the terms "extended pancreatectomy" and "multi-visceral resection" have led to a lack of evidence in terms of indications, surgical outcomes and oncological long-term results for this procedure. In 2014, the International Study Group for Pancreatic Surgery (ISGPS) established an unequivocal definition of 'extended distal pancreatectomy' as a standard distal pancreatectomy (DP) associated with resection of any of the following involved organs: gastric resections, colonic or small bowel resections, left adrenal gland, left kidney, diaphragm, contiguous liver. Major arterial or venous resections were also included in the definition. ${ }^{3}$ Nevertheless, the indications for extended DP are still controversial, particularly in the era of neoadjuvant treatments, with only heterogeneous data available to assess its results.

We present here a case of a locally advanced tumor of the pancreatic tail wherein extended DP with combined multi-visceral resection and thoracic wall resection was performed after a long-course downstaging, along with a brief literature review.

Received: July 4, 2019; Revised: July 18, 2019; Accepted: July 25, 2019

Corresponding author: Rafael Lopez Andujar

Department of HPB Surgery and Transplant, Hospital Universitario La Fe, Avinguda de Fernando Abril Martorell, 106, València 46026, Spain Tel: +34-961244000, Fax: +34-0458124816, E-mail: rlopezandujar@telefonica.net

Copyright (C) 2020 by The Korean Association of Hepato-Biliary-Pancreatic Surgery

This is an Open Access article distributed under the terms of the Creative Commons Attribution Non-Commercial License (http://creativecommons.org/ censes/by-nc/4.0) which permits unrestricted non-commercial use, distribution, and reproduction in any medium, provided the original work is properly cited. Annals of Hepato-Biliary-Pancreatic Surgery • pISSN: 2508-5778 - elSSN: 2508-5859 


\section{CASE}

A 53-year-old previously healthy man, American Society of Anesthesiologists 2, complained of epigastric abdominal pain irradiating to the left flank, associated with $8 \mathrm{~kg}$ weight loss and low-grade fever over the last 3 months.

Physical examination revealed left upper quadrant abdominal tenderness with no rebound. No jaundice was present. Tumor markers were within normal range with serum carbohydrate antigen 19-9 (CA 19.9) $4.5 \mathrm{U} / \mathrm{ml}$ (normal value (n.v.) $<27 \mathrm{U} / \mathrm{ml}$ ) and serum carcinoembryonic antigen (CEA) $1.2 \mathrm{ng} / \mathrm{ml}$ (n.v. $<5 \mathrm{ng} / \mathrm{ml}$ ). Contrastenhanced computed tomography (CECT) showed a bulky tumor in the left flank, measuring $95 \times 96 \times 75 \mathrm{~mm}$, which involved the tail of the pancreas, the spleen, the splenic flexure of the colon, the left kidney and the left adrenal gland (Fig. 1). A massive retroperitoneal infiltration was present, with extension to the lateral abdominal wall and to the lower ribs. No distant metastasis were detected. The mass was histologically confirmed as biliary-pancreatic tumor by a colonoscopic biopsy. The 18-FDG-PET confirmed elevated metabolic activity of the mass along with enhanced FDG uptake on the left thoracic wall and left anterior costovertebral angle. The patient was diagnosed with locally advanced pancreatic cancer of the pancreas tail at the institutional multidisciplinary board, and referred to neoadjuvant treatment. He underwent systemic chemotherapy with FOLFIRINOX (folinic acid 400 $\mathrm{mg} / \mathrm{m}^{2}$, fluorouracil $2,400 \mathrm{mg} / \mathrm{m}^{2}$, irinotecan $180 \mathrm{mg} / \mathrm{m}^{2}$ and oxaliplatin $85 \mathrm{mg} / \mathrm{m}^{2}$ ). Overall, 12 cycles were administer-

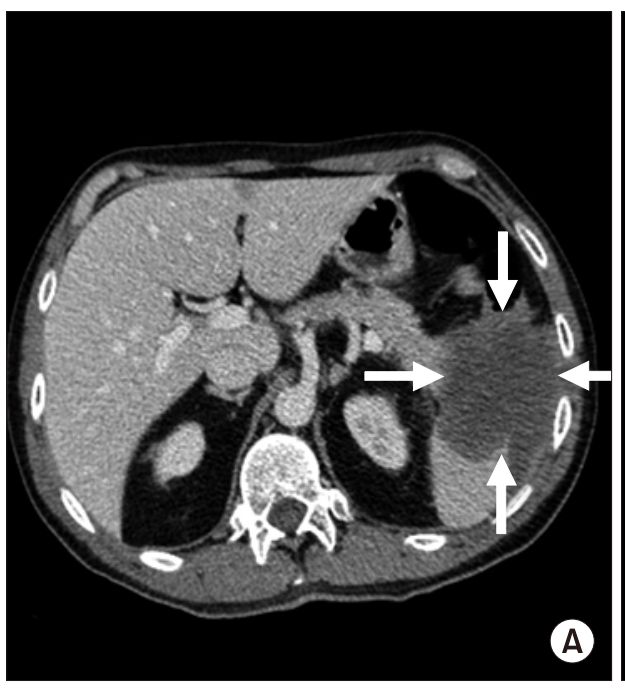

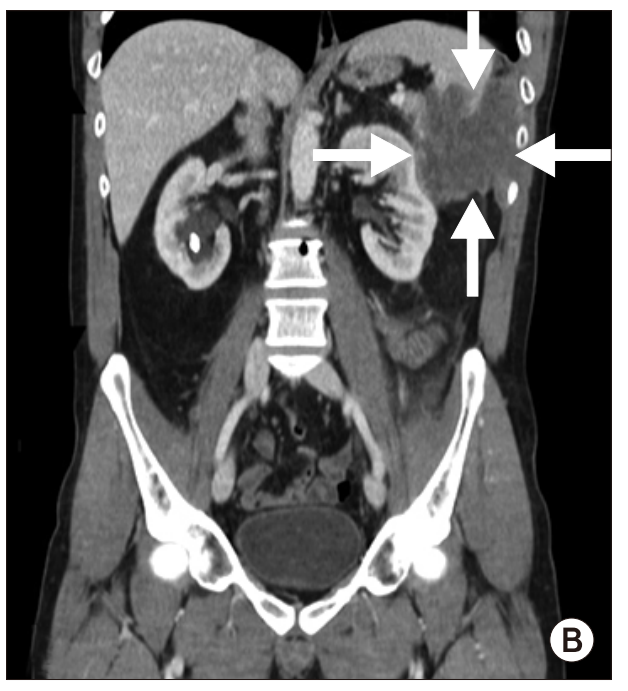

Fig. 1. Axial (A) and coronal (B) CT scan images performed at diagnosis showed a bulky tumor (arrows) of the pancreatic tail involving the surrounding organs and the abdominal wall.
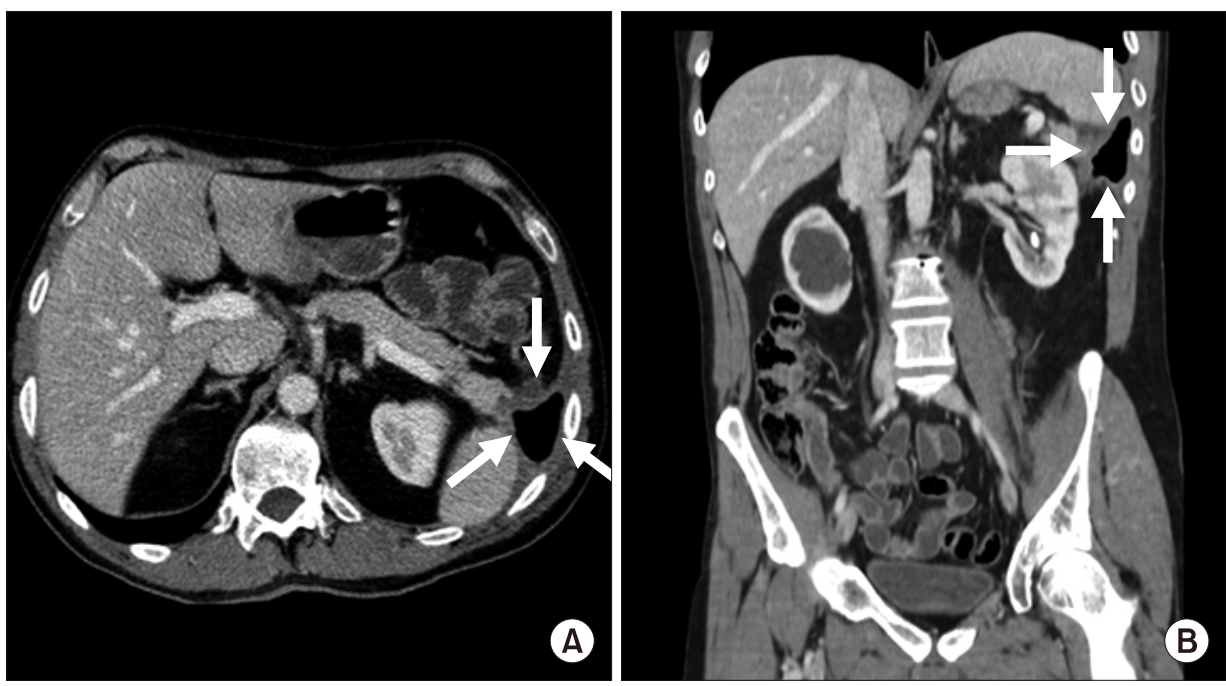

Fig. 2. Axial (A) and coronal (B) CT scan images performed at the end of neoadjuvant treatment showed a significant reduction of the tumor size (arrows) as well as a decreased involvement of adjacent organs. 
ed, two of which with dose reduction to $80 \%$ because of neutropenia.

Beside the above-mentioned side effect, chemotherapy was well tolerated and the time between the beginning of treatment and the last cycle was uneventful, except for one episode of fever and abdominal pain, likely due to a pericolonic abdominal collection with possible colonic leakage as confirmed by the CECT scan. The episode required inpatient conservative treatment with broad spectrum intra-venous antibiotic.

At the CECT for the reevaluation after chemotherapy, the mass was significantly reduced in size, even though borders were barely discernable (Fig. 2). The MRI with paramagnetic contrast confirmed the infiltration of the retroperitoneum, the left perinephric fat and the thoracic wall up to the muscular layer. Tumor markers were still low, with $\mathrm{Ca} 19.94 .0 \mathrm{U} / \mathrm{ml}(\mathrm{n.v}<27 \mathrm{U} / \mathrm{ml})$ and CEA $2.5 \mathrm{ng} / \mathrm{ml}$ (n.v $<5 \mathrm{U} / \mathrm{ml}$ ).

At the institutional tumor board reevaluation after chemotherapy, once the long-course effective neoadjuvant treatment was considered, curative surgery was planned, although R0 resection still seemed to require extended distal pancreatectomy with resection of contiguous organs including the thoracic wall. Surgery was scheduled for 17 days after the end of chemotherapy.

Neither peritoneal dissemination nor distant metastasis was found at laparotomy. After entering the lesser sac by dividing the gastrocolic ligament the tumor was found to involve the pancreatic tail, the spleen, the splenic flexure of the colon, the left perinephric tissues, the diaphragm and the thoracic wall. The left colic vessels were identified and divided and both the transverse colon and the descending were transected with a linear stapler (Echelon Flex $^{\mathrm{TM}}$ GST system, Ethicon ${ }^{\circledR}$ US, LLC) (Fig. 3A). The splenic artery and splenic vein were divided and the splenophrenic ligament was dissected. Once the retropancreatic tunnel was developed, the pancreas was transected by a reinforced stapler (Echelon FlexTM GST system, Ethicon ${ }^{\circledR}$ US, LLC) (Fig. 3B, C). The left renal artery, vein and ureter were divided (Fig. 3D, E) and the left kidney, together with the perinephric fat, was separated up to the iliopsoas plane. A left thoracotomy was performed and the latissimus dorsi muscle was divided (Fig. 4A). After dividing the intercostal muscles and bundles, the $9^{\text {th }}$ and $10^{\text {th }}$
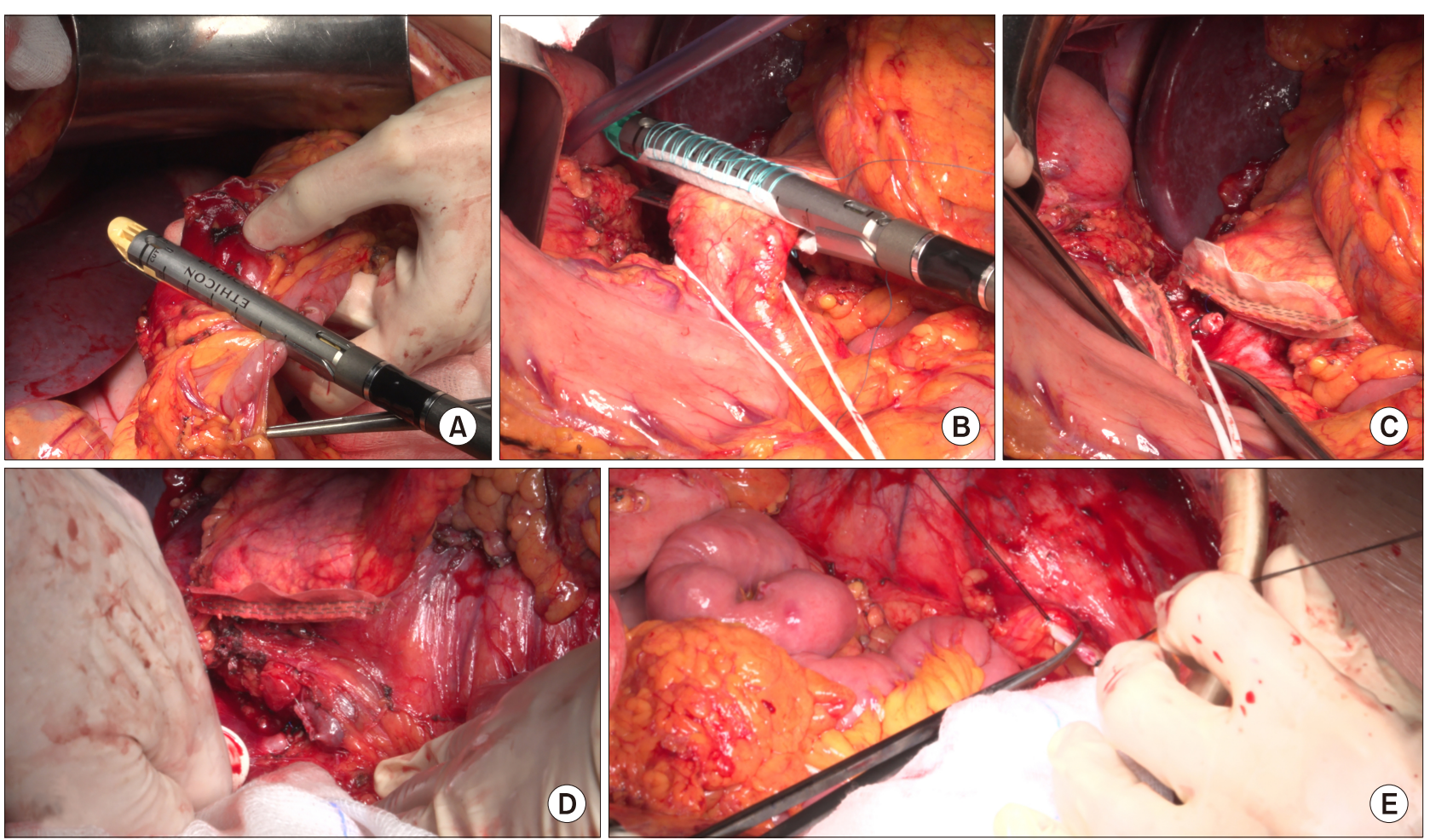

Fig. 3. (A) The transverse colon was transected with a linear stapler. (B) The pancreatic transection was performed by a reinforced stapler. (C) Closure of the pancreatic stump. (D) Left renal artery and vein were divided. (E) Left ureter was identified and divided. 


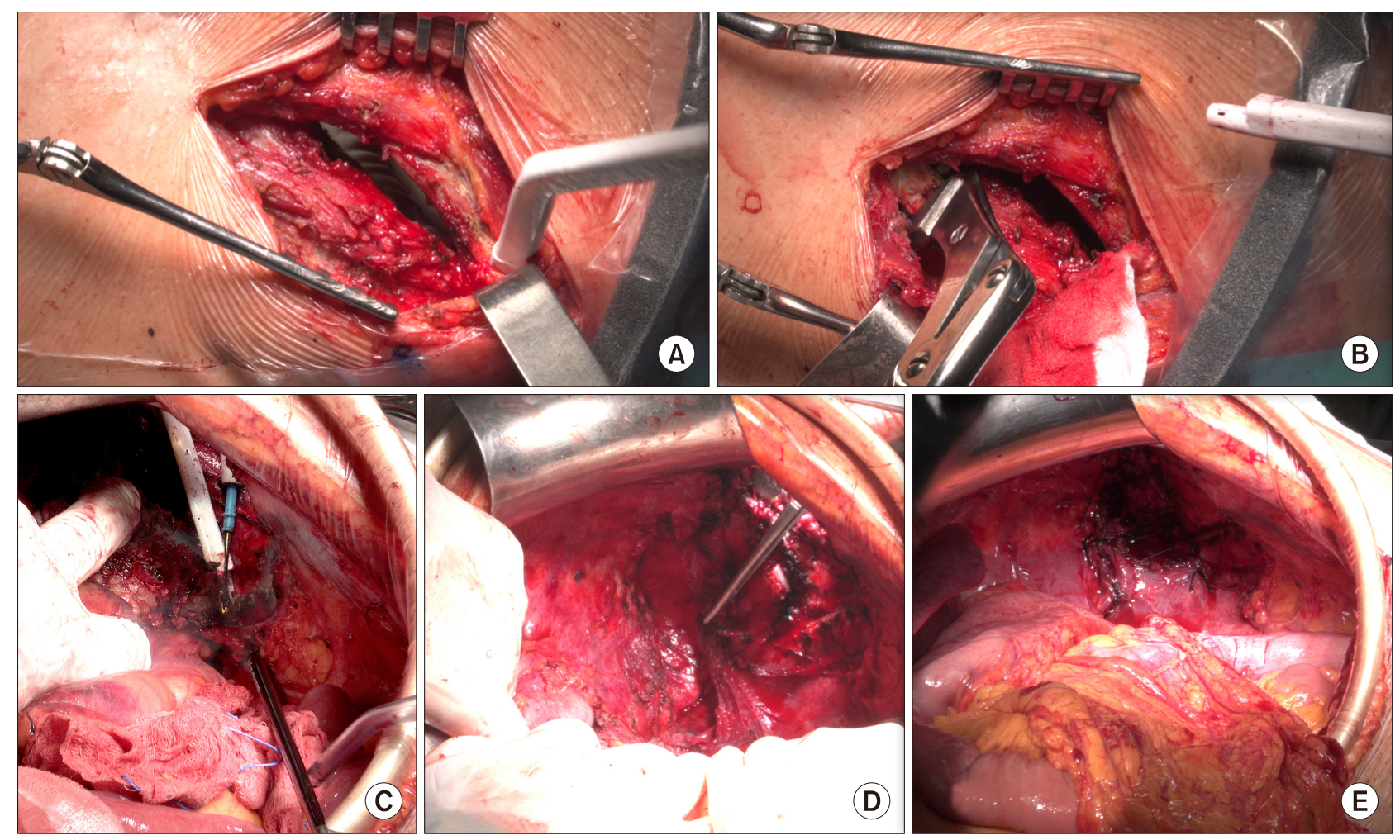

Fig. 4. (A, B) Left thoracotomy was performed and the $9^{\text {th }}$ and the $10^{\text {th }}$ ribs were transected. (C) Pancreatic dissection was extended to left up to the thoracic wall. (D) The specimen was removed en bloc and a wide diaphragmatic defect was observed. (E) The thoracotomy and the diaphragmatic defect were directly repaired.

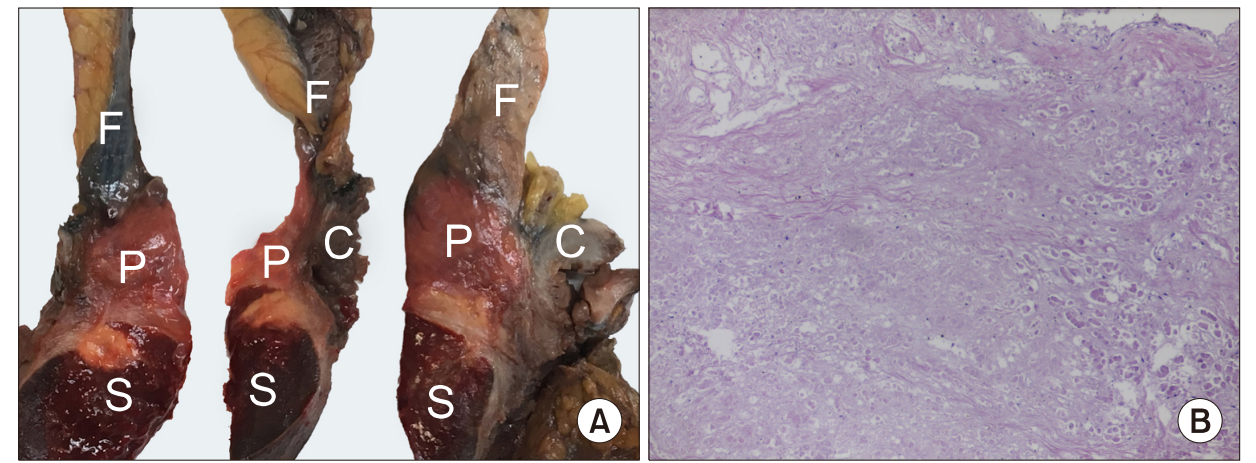

Fig. 5. (A) The macroscopic analysis (A) of the specimen included the tail of the pancreas (P), the spleen (S), the left kidney, the left colonic flexure (C) the left adrenal and the thoracic wall resection. Peripancreatic fat (F) is also shown. (B) Histological exam with $H \& E$ stain revealed complete response with diffuse fibrosis. No viable tumor cells were detected. ribs were identified and transected anteriorly and posteriorly to the tumor's infiltration (Fig. 4B). Pancreatic dissection was then extended to the left and around the tumor, including part of the lateral diaphragm (Fig. 4C). The resected thoracic wall was eventually removed en bloc with the specimen (Fig. 4D). Lymph node stations 8a, 8p, $9,12 \mathrm{a}, 12 \mathrm{p}$ and $12 \mathrm{~b}$ were selectively sampled. Because of the contaminated field due to the pre-operative collection and the colonic resection, the use of a mesh was unadvisable. Thoracotomy was directly repaired, as well as the diaphragmatic defect (Fig. 4E). Two running ab- sorbable sutures were used for the end-to-end colonic anastomosis and one closed-system suction drain was left in close proximity to the tumor bed. The overall operative time was 390 minutes and no blood transfusions were required. Patient was admitted to the Intensive Care Unit for 24-hour monitoring and eventually transferred to the ward.

The early post-operative course was uneventful and patient was discharged on post-operative day (POD) 7 . He was subsequently readmitted on POD 17 because of fever associated with upper abdominal pain and a CT scan evi- 
dence of an abdominal sub-phrenic collection. The treatment consisted of a percutaneous drainage, and amylases rich fluid was collected. Patient was diagnosed with grade $\mathrm{B}$ post-operative pancreatic fistula $(\mathrm{POPF})^{7}$ and finally discharged. The percutaneous drain was removed on POD 29 at the outpatient clinic.

Final pathology showed complete response of the pancreatic cancer. No viable tumor cells could be identified in the specimens and all margins of resection were negative for tumor infiltration (R0) (Fig. 5). Tumor stage was pT0, pN0 (0/41), M0.

At the 6-month post-operative follow-up, the patient was doing well and no recurrence of disease was detectable at the CECT scan.

\section{DISCUSSION}

Indications and outcomes of extended pancreatectomy have been barely investigated and no definitive conclusions have been drawn. Beside providing unambiguous definitions for different types of extended pancreatectomy, the International Study Group for Pancreatic Surgery (ISGPS) aimed to assess post-operative surgical and oncological outcomes of the procedure. Despite the heterogeneity of the available data, they concluded that the long-term survival provided by extended pancreatectomy for pancreatic cancer was similar to that of standard pancreatectomy, with 3-year OS ranging from $16 \%$ to $19.4 \%$. However, increased duration of surgery, blood loss, need for transfusions and overall morbidity, along with longer duration of ICU stay and hospital stay were reported. ${ }^{3}$ Particularly, overall morbidity was assessed between $42 \%$ and $60 \%$ after extended pancreatectomy, and between $34 \%$ and $58 \%$ after standard pancreatectomy.

A subsequent large retrospective monocentric analysis on 611 consecutive cases by Hartwig et al. ${ }^{6}$ confirmed a considerable reduction of perioperative outcome for patients undergoing extended pancreatectomy, ${ }^{8}$ with surgical morbidity of $42.7 \%$ (vs $34.2 \%$ among those undergoing standard pancreatectomy) and 30-day mortality of $4.3 \%$. A similar decrease in post-operative outcome was reported by Schwartz et al., ${ }^{9}$ when colectomy was associated to standard pancreatectomy, with 30-day morbidity increasing from $37 \%$ to $54 \%$ and mortality from $2 \%$ to $9 \%$. Nevertheless, in a recent study, Mitra et al. found no sig- nificant differences in peri-operative morbidity $(37 \%$ vs $29 \%$ ) and mortality (6\% vs $4 \%$ ) among patients undergoing extended pancreatectomy when compared to standard pancreatectomy, and similar conclusions were reported by Low et al. ${ }^{10}$ by analyzing a small retrospective cohort.

Other series only focused on indications and outcomes of extended DP. Roch et al. ${ }^{11}$ compared patients undergoing standard DP with those undergoing extended DP in a retrospective analysis. They concluded that similar morbidity and mortality were found between the two groups as well as comparable oncological results. Panzeri et al. ${ }^{12}$ reported acceptable morbidity and long-term survival among patients undergoing DP associated with multi-visceral resections. Finally, in a retrospective case-matched analysis by Malinka et al. ${ }^{5}$ no differences in terms of complications and survival between standard DP and DP combined with multi-visceral resections were detected. Table $1^{3,5,6,9-14}$ summarizes the studies including series of extended DP and published subsequently to the ISGPS group consensus paper (2014).

Despite the definition provided by the ISPGS group, firm conclusions about indications and outcomes of extended DP are yet to be reached, partially due to the misleading use of the terms 'multi-visceral resection' and extended DP, which included also major vascular resections. Many of the reported series analyzed both extended pancreaticoduodenectomy and extended DP, without providing any subgroup analysis and often including both pancreatic ductal adenocarcinoma and non-malignant diseases. Moreover, none of them focused on the role of neoadjuvant treatments, neither as possible selection tool for surgery nor as a potential predictor of outcome.

Neoadjuvant strategies such as chemotherapy and radiotherapy have shown to have a key role in terms of disease control and effective downstaging, with excellent rates of subsequent radical resections. ${ }^{15-18}$

It is well accepted, therefore, that patients with locally advanced or borderline resectable pancreatic cancer should undergo neoadjuvant treatments at first, with upfront surgery remaining a viable option mainly for those with resectable tumors. Despite the lack of evidence supporting the role of neoadjuvant therapy for bulky tumors with involvement of adjacent organs, ${ }^{19}$ preoperative downstaging might be helpful in these cases too, by reducing the tumor burden, minimizing the extension of surgical re- 
Table 1. Studies including series of EDP and published following the ISPGS consensus paper ${ }^{3}$

\begin{tabular}{|c|c|c|c|c|c|c|c|c|}
\hline Authors & Year & Design & $\begin{array}{l}\text { Number of } \\
\text { cases of } \\
\text { extended distal } \\
\text { pancreatectomy } \\
\text { (EDP) }\end{array}$ & Histology & $\begin{array}{l}\text { Number (\%) } \\
\text { of patients } \\
\text { undergoing EDP } \\
\text { after neoadjuvant } \\
\text { chemotherapy }\end{array}$ & $\begin{array}{c}\text { Surgical } \\
\text { outcomes } \\
\text { (EDP vs SDP) }\end{array}$ & $\begin{array}{l}\text { Oncological results } \\
\text { (EDP vs SDP) }\end{array}$ & R0/R1 \\
\hline $\begin{array}{l}\text { Roch } \\
\text { et al. }\end{array}$ & 2015 & $\begin{array}{c}\text { Retrospective } \\
\text { not matched } \\
\text { case-control }\end{array}$ & 23 & $\begin{array}{l}\text { Adeno- } \\
\text { carcinoma }\end{array}$ & $2(2.9 \%)$ & $\begin{array}{l}\text { Morbidity: } \\
69.6 \% \text { vs } 61.4 \% \\
30 \text {-day mortality: } \\
0 \text { vs } 1.4 \%\end{array}$ & $\begin{array}{l}\text { Median } \\
\text { survival: } 20.3 \\
\text { vs } 16 \text { months } \\
\text { DFS: } 13.2 \text { vs } \\
10.4 \text { months }\end{array}$ & $\begin{array}{l}\text { R0 } 78.3 \% \\
\text { R1 } 21.7 \%\end{array}$ \\
\hline $\begin{array}{l}\text { Hartwig } \\
\text { et al. }\end{array}$ & 2016 & $\begin{array}{l}\text { Retrospective } \\
\text { not matched } \\
\text { case-control }\end{array}$ & 122 & Mixed & N/A & $\begin{array}{r}\text { Surgical morbidity: } \\
42.7 \% \text { vs } 34.2 \% \\
90 \text {-days mortality: } \\
10.8 \% \text { vs } 5.3 \%\end{array}$ & $\begin{array}{l}\text { 5-year OS: } \\
11.3 \% \text { vs } \\
20.6 \%\end{array}$ & $\begin{array}{ll}\text { R0 } & 38.7 \% \\
\text { R1 } & 58 \% \\
\text { R2 } & 3.3 \%\end{array}$ \\
\hline $\begin{array}{l}\text { Panzeri } \\
\text { et al. }\end{array}$ & 2017 & $\begin{array}{l}\text { Retrospective } \\
\text { not matched } \\
\text { case-control }\end{array}$ & 59 & Mixed & $13(31.7 \%)$ & $\begin{array}{l}\text { Morbidity: } \\
69.5 \% \text { vs } 57.2 \% \\
30 \text {-day mortality: } \\
1.7 \% \text { vs } 0\end{array}$ & $\begin{array}{l}\text { Median } \\
\text { survival: } 27 \text { vs } \\
37 \text { months }\end{array}$ & N/A \\
\hline $\begin{array}{l}\text { Sahakyan } \\
\text { et al. }\end{array}$ & 2018 & $\begin{array}{l}\text { Retrospective } \\
\text { not matched } \\
\text { case-control }\end{array}$ & 31 & $\begin{array}{l}\text { Mixed } \\
(24 \text { adeno- } \\
\text { carcinoma) }\end{array}$ & None & $\begin{array}{l}\text { Morbidity: } \\
36 \% \text { vs } 32 \% \text {. } \\
\text { Similar Hospital } \\
\text { staying. }\end{array}$ & $\begin{array}{l}\text { Median } \\
\text { survival: } 12.9 \\
\text { vs } 27 \text { months } \\
\text { DFS: } 6.2 \text { vs } 9.6 \\
\text { months }\end{array}$ & N/A \\
\hline $\begin{array}{l}\text { Malinka } \\
\text { et al. }\end{array}$ & 2018 & $\begin{array}{l}\text { Retrospective } \\
\text { matched } \\
\text { case-control }\end{array}$ & 126 & $\begin{array}{l}\text { Mixed } \\
\text { (65 adeno- } \\
\text { carcinoma) }\end{array}$ & $\mathrm{N} / \mathrm{A}$ & $\begin{array}{l}\text { Major } \\
\text { complications: } \\
19.8 \% \text { vs } 15.9 \% \\
90 \text {-days mortality: } \\
2.4 \% \text { vs } 0.8 \%\end{array}$ & $\begin{array}{l}\text { Median } \\
\text { survival: } 29 \text { vs } \\
34 \text { moths }\end{array}$ & N/A \\
\hline $\begin{array}{l}\text { Mitra } \\
\text { et al. }\end{array}$ & 2018 & $\begin{array}{c}\text { Retrospective } \\
\text { not matched } \\
\text { case-control }\end{array}$ & 19 & $\begin{array}{l}\text { Mixed } \\
\text { (27 adeno- } \\
\text { carcinoma) }\end{array}$ & $11 \%$ & $\begin{array}{l}\text { Morbidity: } \\
36.5 \% \text { vs } 29 \% \\
90 \text {-day mortality: } \\
6 \% \text { vs } 4 \%\end{array}$ & $\begin{array}{l}\text { Median } \\
\text { survival: } 9.5 \\
\text { vs } 19.5 \text { months } \\
\text { 3-years DFS: } \\
41 \% \text { vs } 67 \%\end{array}$ & $\begin{array}{ll}\text { R0 } & 79.4 \% \\
\text { R1 } & 17.5 \% \\
\text { R2 } & 1.6 \%\end{array}$ \\
\hline $\begin{array}{l}\text { Low } \\
\text { et al. }{ }^{10 a}\end{array}$ & 2018 & $\begin{array}{c}\text { Retrospective } \\
\text { not matched } \\
\text { case-control }\end{array}$ & 3 & $\begin{array}{l}\text { Mixed } \\
(22 \text { adeno- } \\
\text { carcinoma) }\end{array}$ & N/A & $\begin{array}{l}\text { Morbidity: } \\
60 \% \text { vs } 46.2 \% \\
30 \text {-day mortality: } \\
0 \text { vs } 1.5 \%\end{array}$ & N/A & N/A \\
\hline $\begin{array}{l}\text { Schwartz } \\
\text { et al. }{ }^{9}\end{array}$ & 2018 & $\begin{array}{r}\text { Retrospective } \\
\text { not-matched } \\
\text { case-control }\end{array}$ & 16 & Mixed & N/A & $\begin{array}{l}\text { Morbidity: } 44 \% \\
90 \text {-day mortality: } \\
6 \%\end{array}$ & N/A & N/A \\
\hline
\end{tabular}

EDP, extended distal pancreatectomy; SDP, standard distal pancreatectomy; N/A, not available

${ }^{a}$ The study includes both extended pancreaticoduodenectomy and EDP, but does not report any subgroup analysis

section and eventually increasing the chance to achieve negative margins. However, once maximized, long-course neoadjuvant treatments have been applied, as in the case we reported, surgical resection represents the last curative option, even though patients still have locally advanced tumors with invasion of contiguous organs. In this setting, challenging and technically demanding surgeries like extended pancreatectomy, with major vascular resections or resection of adjacent organs, should be considered, and the limit of resection might be tailored on every single case.

Highly selected patients with borderline resectable and locally advanced pancreatic tumors affecting adjacent structures might be eligible for extended pancreatic resections, particularly after pre-operative maximized neoadjuvant treatment and following a multidisciplinary evaluation. In high-volume centers with ample experience in pancreatic surgery, extended pancreatectomies represent a viable curative chance with acceptable post-operative morbidity and mortality. Challenging tailored extended re- 
sections might be taken into account, as an attempt to achieve negative margins.

\section{ORCID}

Tommaso Giuliani: https://orcid.org/0000-0003-0794-5253

Maria López Rubio: https://orcid.org/0000-0003-3625$585 \mathrm{X}$

Eva Montalvá Oron:. https://orcid.org/0000-0002-85631340

Javier Maupoey Ibañez: https://orcid.org/0000-0001-6378498X

Andrea Boscá Robledo: https://orcid.org/0000-00021462-3028

Cecilia López Valdivia: https://orcid.org/0000-00016853-1500

Judith Pérez Rojas: https://orcid.org/0000-0001-9558-654X

Rafael Lopez Andujar: https://orcid.org/0000-0002-47670357

\section{AUTHOR CONTRIBUTIONS}

Intellectual property: TG. Data production: RLA, CLV, JPR. Data collection: TG, MLR. Methodology: ABR, JMI. Writing - original draft: TG, MLR. Writing - review and editing: EMO, RLA.

\section{REFERENCES}

1. Butturini G, Stocken DD, Wente MN, Jeekel H, Klinkenbijl JH, Bakkevold KE, et al;; Pancreatic Cancer Meta-Analysis Group. Influence of resection margins and treatment on survival in patients with pancreatic cancer: meta-analysis of randomized controlled trials. Arch Surg 2008;143:75-83; discussion 83 .

2. Konstantinidis IT, Warshaw AL, Allen JN, Blaszkowsky LS, Castillo CF, Deshpande V, et al. Pancreatic ductal adenocarcinoma: is there a survival difference for $\mathrm{R} 1$ resections versus locally advanced unresectable tumors? What is a "true" R0 resection? Ann Surg 2013;257:731-736.

3. Hartwig W, Vollmer CM, Fingerhut A, Yeo CJ, Neoptolemos JP, Adham M, et al.; International Study Group on Pancreatic Surgery. Extended pancreatectomy in pancreatic ductal adenocarcinoma: definition and consensus of the International Study Group for Pancreatic Surgery (ISGPS). Surgery 2014;156:1-14.

4. Loveday BPT, Zilbert N, Serrano PE, Tomiyama K, Tremblay A, Fox AM, et al. Neoadjuvant therapy and major arterial resection for potentially reconstructable arterial involvement by stage 3 adenocarcinoma of the pancreas. HPB (Oxford) 2019;21: 643-652.

5. Malinka T, Klein F, Andreou A, Pratschke J, Bahra M. Distal pancreatectomy combined with multivisceral resection is associated with postoperative complication rates and survival comparable to those after standard procedures. J Gastrointest Surg 2018;22:1549-1556.

6. Hartwig W, Gluth A, Hinz U, Koliogiannis D, Strobel O, Hackert $\mathrm{T}$, et al. Outcomes after extended pancreatectomy in patients with borderline resectable and locally advanced pancreatic cancer. Br J Surg 2016;103:1683-1694.

7. Bassi C, Marchegiani G, Dervenis C, Sarr M, Abu Hilal M, Adham M, et al.; International Study Group on Pancreatic Surgery (ISGPS). The 2016 update of the International Study Group (ISGPS) definition and grading of postoperative pancreatic fistula: 11 years after. Surgery 2017;161:584-591.

8. Bhayani NH, Enomoto LM, James BC, Ortenzi G, Kaifi JT, Kimchi ET, et al. Multivisceral and extended resections during pancreatoduodenectomy increase morbidity and mortality. Surgery 2014;155:567-574.

9. Schwartz PB, Roch AM, Han JS, Vaicius AV, Lancaster WP, Kilbane EM, et al. Indication for en bloc pancreatectomy with colectomy: when is it safe? Surg Endosc 2018;32:428-435.

10. Low TY, Koh YX, Teo JY, Goh BKP. Short-term outcomes of extended pancreatectomy: a single-surgeon experience. Gastrointest Tumors 2018;4:72-83.

11. Roch AM, Singh H, Turner AP, Ceppa EP, House MG, Zyromski NJ, et al. Extended distal pancreatectomy for pancreatic adenocarcinoma with splenic vein thrombosis and/or adjacent organ invasion. Am J Surg 2015;209:564-569.

12. Panzeri F, Marchegiani G, Malleo G, Malpaga A, Maggino L, Marchese T, et al. Distal pancreatectomy associated with multivisceral resection: results from a single centre experience. Langenbecks Arch Surg 2017;402:457-464.

13. Sahakyan MA, Kleive D, Kazaryan AM, Aghayan DL, Ignjatovic $\mathrm{D}$, Labori KJ, et al. Extended laparoscopic distal pancreatectomy for adenocarcinoma in the body and tail of the pancreas: a single-center experience. Langenbecks Arch Surg 2018;403:941-948.

14. Mitra A, Pai E, Dusane R, Ranganathan P, DeSouza A, Goel $\mathrm{M}$, et al. Extended pancreatectomy as defined by the ISGPS: useful in selected cases of pancreatic cancer but invaluable in other complex pancreatic tumors. Langenbecks Arch Surg 2018;403: 203-212.

15. Shubert CR, Bergquist JR, Groeschl RT, Habermann EB, Wilson PM, Truty MJ, et al. Overall survival is increased among stage III pancreatic adenocarcinoma patients receiving neoadjuvant chemotherapy compared to surgery first and adjuvant chemotherapy: an intention to treat analysis of the National Cancer Database. Surgery 2016;160:1080-1096.

16. Michelakos T, Pergolini I, Castillo CF, Honselmann KC, Cai L, Deshpande V, et al. Predictors of resectability and survival in patients with borderline and locally advanced pancreatic cancer who underwent neoadjuvant treatment with FOLFIRINOX. Ann Surg 2019;269:733-740.

17. Choi JG, Nipp RD, Tramontano A, Ali A, Zhan T, Pandharipande $P$, et al. Neoadjuvant FOLFIRINOX for patients with borderline resectable or locally advanced pancreatic cancer: results of a decision analysis. Oncologist 2019;24:945-954.

18. Moningi S, Dholakia AS, Raman SP, Blackford A, Cameron JL, Le DT, et al. The role of stereotactic body radiation therapy for pancreatic cancer: a single-institution experience. Ann Surg Oncol 2015;22:2352-2358.

19. Kaiser J, Hackert T, Büchler MW. Extended pancreatectomy: does it have a role in the contemporary management of pancreatic adenocarcinoma? Dig Surg 2017;34:441-446. 